\title{
IMMUNOCHEMICAL ANALYSIS OF BUCKWHEAT PROTEINS, PROLAMINS AND THEIR ALLERGENIC CHARACTER
}

\author{
E. AUBRECHT and P. Á. BIACS \\ Central Food Research Institute H-1022 Budapest, Herman Ottó út 15. Hungary \\ (Received: 16 November 1998; accepted: 11 March 1999)
}

Prolamin content of buckwheat flour and processed foods was $24.2-42.1 \mathrm{mg} / \mathrm{kg}$ dry material measured by ELISA. According to in vitro results buckwheat is suitable for use in coeliac diet, although it contains some antinutritive materials, protease inhibitors and tannin. The allergenic properties of buckwheat are poorly understood. In our investigation intensity of the $24 \mathrm{kD}$ protein band of buckwheat, of which allergenic activity is known has decreased, and $30-35 \mathrm{kD}$ protein associations have been formed after heat treatment. Immunochemical reaction of buckwheat proteins were studied with blood specimens of coeliac and healthy persons.

Keywords: buckwheat prolamin, gluten-free, coeliac, allergen

Currently, the only help for coeliac patients, who do not tolerate wheat gliadins in their food, is a gluten-free diet. The main problem connected with the gluten-free food produced from seeds of maize and rice is the quick staling. This problem could be eliminated by the use of buckwheat seed. The products prepared from it can be kept fresh for a long time.

The buckwheat (Fagopyrum esculentum Moench) belongs botanically to Polygonaceae, it is far from Graminaceae family. Buckwheat seed can be applied for human nutrition only after dehulling, as there are toxic substances included in the hull of the seeds. Dehulled seed, flour milled from this seed and grits can be used for the preparation of meals. Protein and carbohydrate contents of buckwheat seed are nearly similar to those of corn and rice. The predominant storage protein of buckwheat seed is $13 \mathrm{~S}$ globulin. This protein has a hexametric structure with disulfide-bonded subunits composed of acidic and basic polypeptides. This structure is common for all legumelike storage proteins (MAKSIMOVIC et al., 1996). Buckwheat flours are rich in albumin and globulin, but they have a lower content of prolamin and glutenin than wheat flour (WEI et al., 1995). Buckwheat is rich in minerals, micro-elements and vitamins (especially vitamin $\mathrm{B}_{1}$ and $\mathrm{B}_{2}$ ), and it is an important source of vitamin $\mathrm{E}$.

The aim of our immunochemical studies was to study in coeliac and non-coeliac patients whether buckwheat flours, grits and their products can be applied for the 
nutrition of patients with wheat flour sensitivity or not. This work is important as glutenfree diets exclude wheat gliadin and other proteins with homologous structure. Gluten content should not exceed the $100 \mathrm{mg}$ gliadin/ $\mathrm{kg}$ dry material amount in the gluten-free diet. This limit has been proposed by the Codex Alimentarius, in the recommendation of FAO/WHO (1998), it was published as ALINORM 97/26, Appendix V.

\section{Materials and methods}

\subsection{Materials}

1.1.1. Samples. Buckwheat seeds, grits, flours, bread, cake (muffin) were gifts from Food Technology Department of Central Food Research Institute (KÉKI). Positive sample GK Öthalom wheat flour was a product of the Cereal Research Institute, Szeged. Rice and glucono-delta-lakton (GDL) were purchased at store.

1.1.2. Anti-gliadin rabbit serum was developed in our laboratory against $30 \mathrm{kD}$ gliadin, antigen was bought from Serva Co. Human sera specimen of coeliac (C) and healthy $(\mathrm{H})$ people were derived from the Department of Dermatology of the Semmelweis University Medical School, Budapest.

1.1.3. Chemicals, reagents for ELISA, and SDS-PAGE. All chemicals were of analytical grade. Antigliadin-rabbit IgG was developed at KÉKI. Antigliadin-rabbithorse-radish-peroxidase (HRP) conjugate were prepared at the Biology Department of KÉKI according to NAKANE and KAWASI (1974).

Goat anti-human IgG-HRP-conjugat and goat anti-rabbit IgG were purchased from Sigma Co. 3,3', 5,5'-tetramethyl benzidine (TMB) substrate (Sigma Co.) was used. Microtiter plates were bought from the Company of Instrument and Plastic Material, Sülysáp, Hungary.

\subsection{Methods}

1.2.1. Prolamin/gliadin extraction. Samples (flours and grits, $100 \mathrm{mg}$ ) and food were mixed with $1 \mathrm{~cm}^{3}$ of $70 \%(\mathrm{v} / \mathrm{v})$ aqueous ethanol in Eppendorf tube and extracted with vigorous shaking on a flash shaker (IKA-Schüttler MTS 4, 700 r.p.m. for $30 \mathrm{~min}$ at $4{ }^{\circ} \mathrm{C}$ ). Following extraction, the samples were centrifuged (T 24 D, 5000 r.p.m. for 20 $\mathrm{min}$ at room temperature), the supernatant was separated and buckwheat samples were concentrated by evaporation of alcohol solution and then used for ELISA.

1.2.2. Sandwich ELISA for prolamin content (AUBRECHT \& TÓTH, 1995). Wells of microplate were incubated overnight at $4{ }^{\circ} \mathrm{C}$ with anti-gliadin rabbit IgG antibody diluted 1:200 from stock solution in $0.05 \mathrm{~mol} \mathrm{Na-carbonate-bicarbonate} \mathrm{buffer} \mathrm{(pH} \mathrm{9.6)}$ (as a coating buffer). Following washing, the wells were incubated with $0.5 \%$ gelatine for $1 \mathrm{~h}$ at $37^{\circ} \mathrm{C}$. After washing, samples diluted in $0.1 \mathrm{~mol}$ PBST pH 7.4 (1:2, 1:50, 
1:200) and gliadin standard in $0.1 \mathrm{~mol}$ PBST (3 $000 \mathrm{ng}, 1000 \mathrm{ng}, 300 \mathrm{ng}, 100 \mathrm{ng}$, $50 \mathrm{ng}, 25 \mathrm{ng}, 12.5 \mathrm{ng}, 6.25 \mathrm{ng}, \mathrm{pH} 7.4$ ) were incubated in wells for $1 \mathrm{~h}$ at $37{ }^{\circ} \mathrm{C}$. After 3 cycles of washing anti-gliadin IgG-HRP-conjugate was added, and incubated for $1 \mathrm{~h}$ at $37^{\circ} \mathrm{C}$. Then the plate was washed and dried. Solution of $42 \mathrm{mmol}$ TMB, containing $0.01 \%(\mathrm{v} / \mathrm{v}) \mathrm{H}_{2} \mathrm{O}_{2}$, was added to each well. After 15 min the reaction was stopped by adding $0.07 \mathrm{~cm}^{3}$ of $2 \mathrm{~mol}$ sulfuric acid and optical densities in the wells were measured at $450 \mathrm{~nm}$.

1.2.3. Indirect ELISA for immunochemical reaction of human sera. Microtiter plates were incubated overnight at $4{ }^{\circ} \mathrm{C}$ with antigens: gliadin $30 \mathrm{kD}$ (3 $000 \mathrm{ng}$, $1000 \mathrm{ng}, 300 \mathrm{ng}, 100 \mathrm{ng}, 50 \mathrm{ng}, 25 \mathrm{ng}, 12.5 \mathrm{ng}, 6.25 \mathrm{ng}$ ) wheat flour GK Öthalom as a positive sample (1:200) and buckwheat samples (1:5) in coating buffer ( $\mathrm{pH} 9.6)$. After 3 -cycle washing $0.5 \%$ gelatine was added and incubated for $1 \mathrm{~h}$ at $37^{\circ} \mathrm{C}$. After washing, coeliac and healthy human sera were added in 1:20 dilution. After incubation at $37^{\circ} \mathrm{C}$ for $1 \mathrm{~h}$ the wells were washed, then $0.1 \mathrm{~cm}^{3}$ of horse-radish peroxidase-conjugated goat anti-human IgG diluted in 0.1 mol PBS ( $\mathrm{pH} 7.4,1: 500)$ was added to each well. Reagents were then incubated at $37^{\circ} \mathrm{C}$ for $1 \mathrm{~h}$ and the excess of reagents was removed by washing with PBST $\left(3 \times 0.3 \mathrm{~cm}^{3} /\right.$ well $)$. TMB substrate was added according to the sandwich ELISA.

1.2.4. SDS-PAGE analysis of buckwheat prolamin and protein. For the analysis of extracted samples (total proteins and prolamins) the modified discontinuous buffer system (LAEMMLI, 1970), stacking gel 5\% PAA (polyacrylamide) (5\%, C 2.70\%) separating gel $10 \%$ PAA (T $10 \%$, C 2.7 ) were used. The vertical SDS-PAGE was carried out with the LKB 2050 Midget Electrophoresis Unit. The slabs were stained at room temperature in a solution of $0.2 \%$ brillant Blue R-250 dissolved in $25 \%(\mathrm{v} / \mathrm{v})$ methanol $1-10 \%(\mathrm{v} / \mathrm{v})$ acetic acid. The slabs were evaluated by BIOTEC-Fischer laser video densitometer.

1.2.5. A-PAGE (Acid-PAGE). Prolamin and proteins of buckwheat and wheat gliadin were separated by PAGE at $\mathrm{pH} 3.1$ (A-PAGE) according to LAFIANDRA and KASARDA (1985). The lanes on the slab were evaluated by densitometer.

1.2.6. Baking. Bread was made with a special bread-making technology with glucono-delta-lacton (GDL) from 100\% buckwheat flour. (The recipe is under patenting process.) Muffin was made of $100 \%$ buckwheat flour and pie was made of $100 \%$ wheat flour with ingredients: margarine, egg, salt, and $\mathrm{NaHCO}_{3}$ in a usual way.

\section{Results}

Prolamin content of buckwheat flour and processed food (as presented in Table 1) is under the permitted limit (FAO/WHO, 1998). The prolamin concentrations were $24.2-42.1 \mathrm{mg} / \mathrm{kg}$ dry material measured by ELISA with polyclonal rabbit sera. The 
wheat gliadin and buckwheat prolamin had reaction with human sera. The results of immunochemical reactions can be seen in Table 2.

It is well-known that human sera (normal sera) contain circulating antibody against gliadin in a lower level. Healthy people have a lower immunochemical reaction with wheat gliadin than coeliac patients. Higher values of patients 3 (C) and 5 (C) are caused by diet abuse according to KÁRPÁTI (1998). Both investigated sera (coeliac and healthy) gave reaction with prolamins of buckwheat, but the absorbance values were low.

Table 1

Determination of prolamin content of buckwheat flour and processed food by ELISA method with antigliadin polyclonal rabbit serum

\begin{tabular}{lc}
\hline \multicolumn{1}{c}{ Samples } & $\begin{array}{c}\text { Prolamin content } \\
\text { (mg/kg dry material) }\end{array}$ \\
\hline Buckwheat flour "Bio" & $24.2 \pm 2.81$ \\
Buckwheat bread with GDL & $38.0 \pm 2.19$ \\
Buckwheat bread mix with GDL & $42.1 \pm 3.12$ \\
GK Öthalom wheat flour as a positive sample & $5094 \pm 18.49$ \\
Rice flour as a negative sample & $31.0 \pm 4.18$ \\
\hline
\end{tabular}

The baked products were made of $100 \%$ buckwheat

Table 2

Immunochemical reaction of immune serum of coeliac and healthy people with $70 \%$ ethanol soluble wheat and buckwheat flour

\begin{tabular}{|c|c|c|}
\hline \multirow[t]{2}{*}{$\begin{array}{l}\text { Healthy }(\mathrm{H}) \text { and } \\
\text { coeliac }(\mathrm{C}) \\
\text { sera }\end{array}$} & \multicolumn{2}{|c|}{$\begin{array}{c}\text { Absorbance of } \\
\text { immunochemical reaction } \\
\text { with }\end{array}$} \\
\hline & buckwheat flour & wheat flour \\
\hline $1(\mathrm{C})$ & 0.064 & 0.463 \\
\hline $2(\mathrm{C})$ & 0.080 & 0.363 \\
\hline $3(\mathrm{C})$ & 0.078 & 0.553 \\
\hline $4(\mathrm{C})$ & 0.141 & 0.433 \\
\hline $5(\mathrm{C})$ & 0.153 & 0.591 \\
\hline $1(\mathrm{H})$ & 0.099 & 0.291 \\
\hline $2(\mathrm{H})$ & 0.032 & 0.296 \\
\hline $3(\mathrm{H})$ & 0.096 & 0.191 \\
\hline $4(\mathrm{H})$ & nd & 0.119 \\
\hline $5(\mathrm{H})$ & nd & 0.201 \\
\hline
\end{tabular}


nd: no detection

In our SDS-PAGE investigation ethanol soluble buckwheat prolamin fraction was a $12 \mathrm{kD}$ protein, which consisted of three protein subfractions (AUBRECHT \& KÁRPÁTI, 1995; AUBRECHT et al., 1998). They were studied by acid-PAGE. The separated subfractions of $12 \mathrm{kD}$ protein, compared with wheat gliadin can be seen in Fig. 1. The three subfractions are marked in the electrophoretogram $(1,2,3 \downarrow \downarrow \downarrow)$. This investigation has proved that buckwheat was gluten-free because the molecular weight distribution of the three subfractions differed from that of wheat. The acid-PAGE is special for wheat gliadin and it did not give the same result with buckwheat prolamins.

The other question in our investigation was that whether the $24 \mathrm{kD}$ protein caused allergenic reaction in human diet (BIACS \& AUBRECHT, 1998). The pattern of whole buckwheat protein from different origin, the wheat and oat samples can be seen in Fig. 2. The $24 \mathrm{kD}$ protein band is predominant, intensive protein on the slab. The $24 \mathrm{kD}$ buckwheat protein was shown by immunoblotting analysis to be the most frequently recognised allergen, binding to IgE antibodies from the patients' sera (KONDO et al., 1996) with RAST (Radio Allergosorbent Test). After baking muffin from buckwheat, intensity the predominant protein band has decreased and $30 \mathrm{kD}$ and $35 \mathrm{kD}$ bands have risen on slab in Fig. 2. The allergenic activity of the latest bands have not yet been known until now.

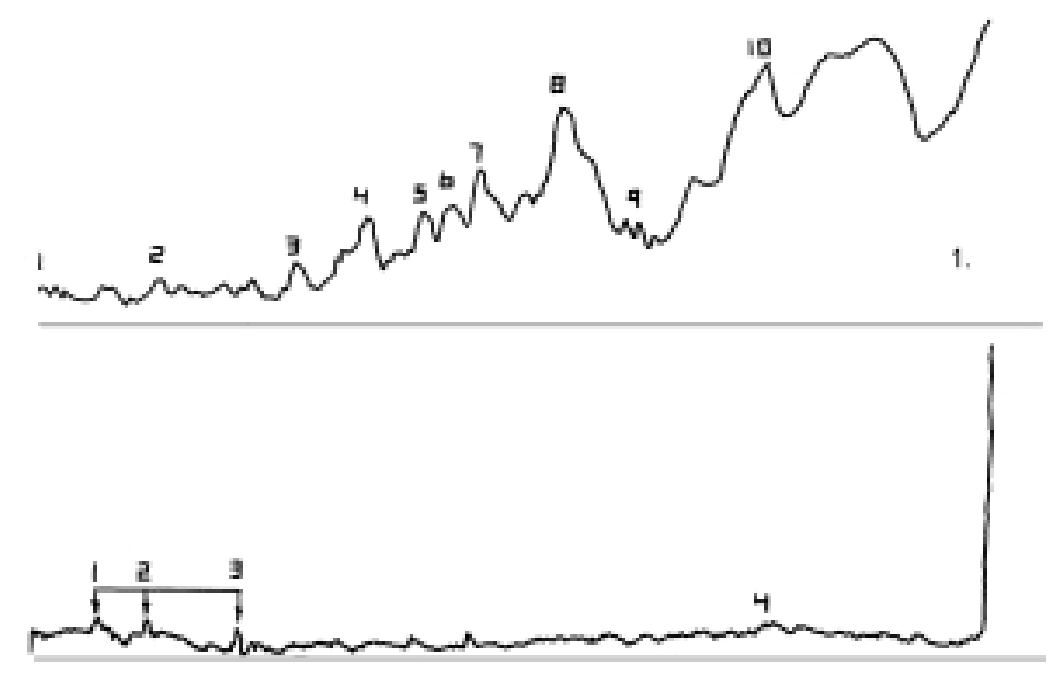

Fig. 1. Electrophoretogram of wheat gliadin (1) and buckwheat prolamin bands (2) 


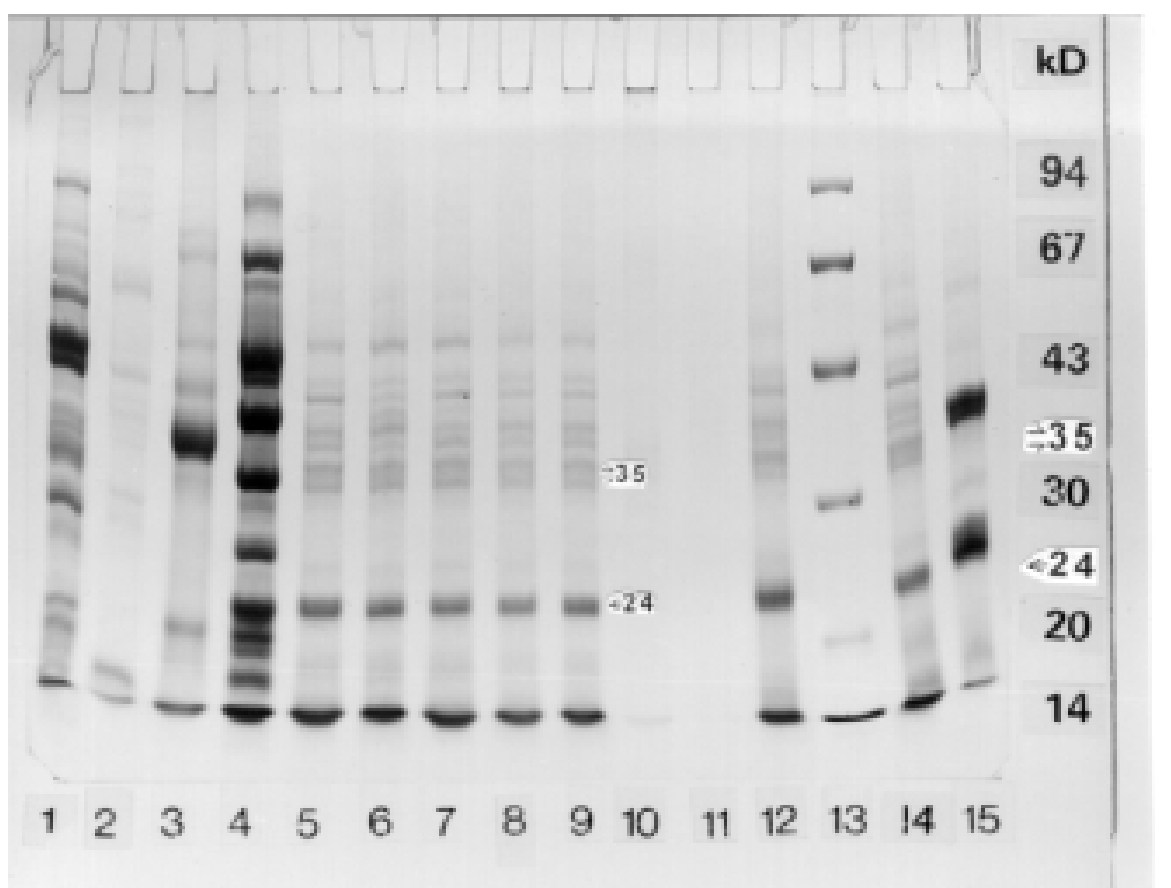

Fig. 2. SDS PAGE of whole protein of buckwheat and different cereals. Lane 1: Kamut organic culture of wheat; lane 2: GK Öthalom wheat; lane 3: Tiszadur durum wheat; 4: Tönköly (Spelta) wheat; lane 5: buckwheat flour; lane 6: buckwheat flour France; lane 7: buckwheat flour Slovene: lane 8: pancake powder 1; lane 9: pancake powder 2; lane 10: cake from 100\% buckwheat flour (muffin); lane 11: cake from $100 \%$ wheat flour (pie); lane 12: noodles made of $100 \%$ buckwheat; lane 13: molecular weight standard; lane 14: buckwheat flour; lane 15: oat bran

\section{Discussion}

It has been proved that buckwheat and wheat prolamins differ. The in vitro results mentioned above suggested that buckwheat can be used in gluten-free diet. Although buckwheat seed is a source of well-balanced protein (POMERANZ \& ROBINS, 1972), seeds have a high level of endogenous antinutrients, protease inhibitor and tannin persisting after cooking (IKEDA et al., 1991).

According to the findings of FRANCISCHI and co-workers (1994) the effect of buckwheat flour ingested by coeliac patients was evaluated by indirect immunofluorescence technique. Serum samples were collected 30 days after the flour ingestion. The assay has revealed that buckwheat flour is not present in the coeliac 
patients. It was observed that anti-prolamin buckwheat antibodies have not been formed during a 30-day assay period. In spite of promising immunological results the allergenic properties have to be studied. KONDO and co-workers (1996) investigated the allergen in buckwheat antigen using the immunoblott method, radioallergosorbent test (RAST) and RAST inhibition assay. Results indicated that the $24 \mathrm{kD}$ buckwheat protein was the major allergen among buckwheat antigens. Buckwheat and rice are frequent foods in Japan and they cause food allergy in some cases (YANO et al., 1989). Our present result suggested that the quantity of allergen could be decreased under baking conditions, however, it has not yet been proved whether muffin (cake made of $100 \%$ buckwheat flour, under the given technology) after digestion will contain reactive groups of $24 \mathrm{kD}$ allergen protein or not. As a result of degradation of $30 \mathrm{kD}$ protein in gut, heat resistant allergen peptides can form and might cause allergenic reaction, too. We are planning to continue our research work to know more about allergenic activity after digestion of the major fractions $(24 \mathrm{kD}, 30 \mathrm{kD})$ in bakery products.

Thanks to Dr S. KÁRPÁTI physician of the Department of Dermatology of the Semmelweis University Medical School, Budapest for human sera specimens, to Mrs F. LÉDER KÉKI Technology Dep. for buckwheat samples, to Mrs M. MOLNÁR for her assistance in laboratory work, to Ms Zs. SzÚCS student of Haynal Imre University of Health Sciences, Department of Dietetics for muffin baked from $100 \%$ buckwheat.

\section{References}

AUBRECHT, E. \& TÓTH, Á. (1995): Investigation of gliadin content of wheat flour by ELISA method. Acta Alimentaria, 24, 23-29.

AUBRECHT, E. \& KÁRPÁTI, M. (1995): Determination of prolamin content of buckwheat by immunochemical method. 9th World Congress of Food Science and Technology 30 July 4. August, Budapest. Poster, Abstract Book p. 141.

AuBrecht, E., HORACSEK, M., GELENCSÉR, É., \& DWORSCHÁK, E. (1998): Investigation of prolamin content of cereals and different seeds. Acta Alimentaria, 27, 119-125.

BiACS, P. Á. \& AUBRECHT, E. (1988): Chemical and immunochemical characterization of buckwheat, application of buckwheat flour in human nutrition and its suggested utilization in dietetic menus in Hungary. 16th ICC Conference 1998. Cereal Science- Its Contribution to Health and Well Being, May 09 Vienna, Austria, Pre-Conference-Symposium: Challenges in Speciality Crops. Poster.

FAO/WHO (1998): Codex Alimentarius Commission FAO/WHO Food Standards Programme. Codex Committee on Nutrition and Foods for Special Dietary uses Twenty-First Session Berlin, Germany, 21-25 September 1998 Draft Revised Standard for Gluten-free Foods (At step 7 of the procedure.) ALINORM 97/26, Appendix V. CX/NFSDU 98/4.

FRANCISCHI, M. L. P. D., SALGADO, J. M. \& COSTA, C. P. D. (1994): Immunological analysis of serum for buckwheat fed celiac patients. Plant Foods for Human Nutrition (Dordrecht), 46, 207-211. 
IKEDA, K. SAKAGUCHI, T. KUSANO, \& YASUMOTO, K. (1991): Endogenous factors affecting digestibility in buckwheat. Cereal Chem., 68, (4) 424-427.

KÁRPÁTI, S. (1998): Personal communication.

KONDO, Y., URISHU, A., WADA, E., TSURUTA, M., YASAKI, T., YAMADA, K., MASADA, S., \& MORITA, Y. (1996): Allergen analysis of buckwheat by the immunoblotting method. Jap. J. Allergology, 42, $142-148$.

LAFINDRA, D. \& KASARDA, D. D. (1985): One and two dimensional polyacrylamide gel electrophoresis in a single gel: separation of wheat proteins. Cereal Chem., 62, 314-319.

LAEMMLI, U. K. (1970): Cleavage of structural proteins during the assembly of head of bacteriophage $\mathrm{T}_{4}$. Nature, 227, 680

MAKSIMOVIC, V. R., VARKONJI-GASIC, R. J., RADOVIC, S. R., \& SAVIC, A. P. (1996): The biosynthesis of 13 S buckwheat seed storage protein. J. Plant Physiol., 147, 759-761.

NAKANE, P. K. \& KAWASI, A. (1974): Peroxidase labelled antibody a new method of conjugation. $J$. Histochem. Cytochem., 22, 1084.

POMERANZ, Y. \& ROBINS, G. S. (1972): Amino acid composition of buckwheat. J. agric. Fd. Chem., 20, $270-275$.

WEI, Y., ZANG, G., Q. \& LI, Z. X. (1995): Study on nutritive and physico-chemical properties of buckwheat flour. Nahrung, 39, 48-54

YANO, M., NAKAMURA, R., HAYAKAWA, S. \& TORII, S. (1989): Purification and properties of allergenic proteins in buckwheat seeds. Agric. biol. Chem., 53, (9), 2387-2392. 